\title{
Cytoplasmic virion assembly compartment of betaherpesviruses
}

\author{
LJERKA KARLEUŠA 1 \\ HANA MAHMUTETFENDIĆ LUČIN ${ }^{1,2}$ \\ GORDANA BLAGOJEVIĆ ZAGORAC ${ }^{1,2}$ \\ PERO LUČIN ${ }^{1,2, *}$ \\ ${ }^{1}$ Department of Physiology and Immunology \\ Faculty of Medicine, University of Rijeka, Rijeka \\ Croatia \\ ${ }^{2}$ University North, University Center Varaždin \\ Varaždin, Croatia \\ *Correspondence: \\ Dr. Pero Lučin \\ pero.lucin@uniri.hr \\ Keywords: betaherpesvirus, cytomegalovirus, \\ virion assembly compartment, endosomal recycling \\ compartment, Rab proteins
}

Received April 22, 2020

Revised July 3, 2020

Accepted July 10, 2020

\begin{abstract}
During their life cycle, betaherpesviruses extensively reorganize the membranous system of the cell in order to develop a unique cytoplasmic environment of virion production ("virus factory"), known as cytoplasmic virion assembly compartment ( $c V A C$ ). The betaherpesvirus $\mathrm{CVAC}$ has been studied both in human and murine cytomegalovirus (CMV) infected cells as they are considered to be models for betaherpesviruses biology. Studies of the cVAC were mainly based on electron microscopy and immunofluorescence tools, and in the previous decade, they have expanded to the use of new technologies and systems approaches (i.e., transcriptomics, proteomics, lipidomics), which led to the acquisition of a vast amount of data. Despite the immense expansion of knowledge about membranous organelle system, including a large amount of data derived from CMV infected cells, the organization and biogenesis of the cVAC remain unclear. Accordingly, very little is known about the processes of a final stage of CMV maturation and the virion egress. This minireview summarizes current knowledge about the biogenesis of the betaherpesvirus factory from the already existent endosomal compartments.
\end{abstract}

\section{INTRODUCTION}

Lerpesviruses (Herpesviridae) are virus family with 107 different 1 species divided into three subfamilies $(1,2)$. They are widely spread between both humans and animals, and share several characteristics such as ubiquity, incurability, reactivation, asymptomatic, and opportunistic infection. Their main functional feature is life-long, latent infection.

All herpesviruses share the fundamental principles of their biology. Their large linear DNA is packaged in the nucleus into an icosahedral protein cage called the viral capsid, which is then embedded into the tegument by a stepwise process of tegumentation and wrapped by membranous-organelle derived a membrane-like lipid bilayer called the (1). This entire particle is then considered as one mature virion, capable of successfully infecting the cell.

There are four members of the betaherpesvirus subfamily known to infect humans. One of them is human cytomegalovirus (HCMV, also known as human herpesvirus 5, HHV-5), which causes asymptomatic infections in the majority of the overall population. It establishes a lifelong latent state from which they can reactivate and cause various pathophysiological alterations, including life-threatening diseases in immunocompromised individuals $(3,4)$. CMV infection is associated with birth defects and congenital abnormalities (5). Human herpesvirus 6A (HHV-6A), HHV-6B, and HHV-7 are also known to infect a high percentage of the human population, similar to HHV-5, and are associ- 


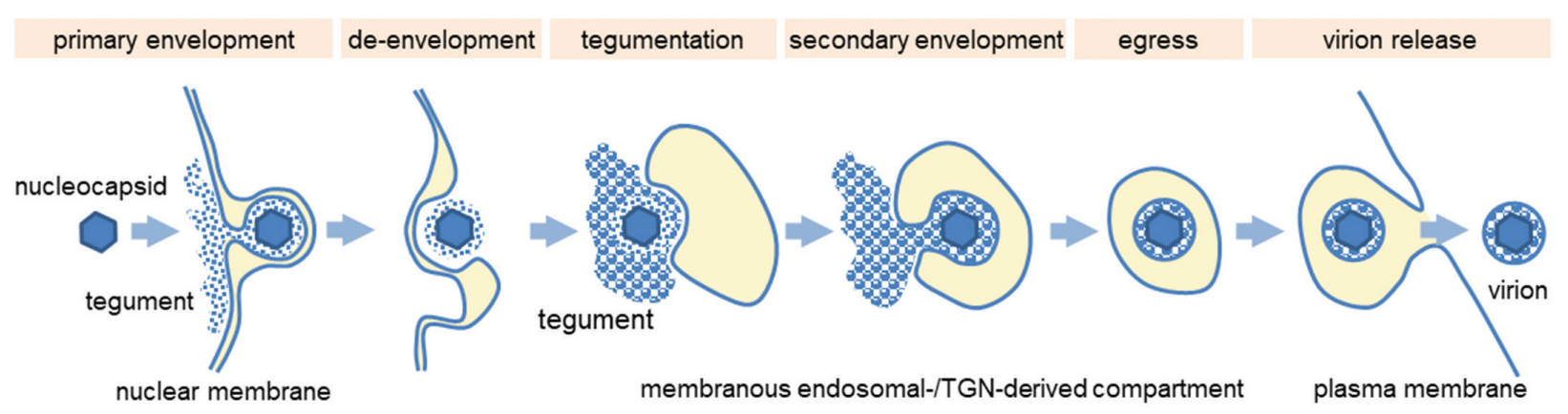

Figure 1. Stages of beta-herpesvirus manufacturing in infected cells. The manufacturing process is divided into seven stages and ends with the release of infectious virions from the cell. At each stage, beta-herpesviruses exploit an appropriate set of cellular functions and reorganize cellular machinery.

ated with various pathophysiological states, including neuroinflammatory diseases, Alzheimer's disease, and the exanthema subitum in infants $(3,4)$.

The development of effective vaccines and antiviral therapies against betaherpesviruses, especially CMV, is among the top priorities in the fight against infectious agents. However, despite the long-lasting efforts throughout the last several decades, effective prevention and therapy of CMV infections are still not achieved (4). Currently, there is no singular therapy for patients with severe, acute HCMV infections, and they are usually treated with antivirals, on a case-by-case basis (6). One of the reasons for the lack of success is an incomplete understanding of CMV biology and pathogenesis, including potential viral and cellular targets of antiviral research. The critical point in the CMV life cycle that could be targeted is host-cell and viral machinery that drives the production of infectious virions during CMV infection.

In this mini-rewiev the main events that occur with the endosomal compartments during the lytic cycle of CMV infection (as model infection for betaherpesviruses) are summarized and brought to a broader herpesvirus audience.

\section{Herpesvirus maturation}

Herpesviruses share general mechanisms for maturation and egress of virions through several budding and fusion events during replication, preventing abrupt disruption of cellular membranes (7). During the productive infection, viral DNA is replicated in the cell nucleus, followed by the synthesis of viral structural proteins used for the formation of capsids (Figure 1). During a process called primary envelopment, complete capsids acquire an envelope by budding through the inner nuclear membrane (INM) into the perinuclear space. These semiproducts in the production of virions undergo de-envelopment, mediated by membrane fusion between the existing primary envelope and the outer nuclear membrane $(\mathrm{ONM})(8,9)$. This means that only the "naked" capsids are delivered into the cytoplasm, where they acquire the final layer of tegument proteins. Tegumentcoated capsids undergo a secondary envelopment by passing through the membranes of different cytoplasmic compartments, gaining their ultimate envelope, and finally, mature virions are produced. Vesicles containing mature virions are then transported to the cell surface where they fuse with the plasma membrane and are released into the extracellular space (Figure 1).

The difference in the production of different herpesvirus subfamilies is most prominent during the stage of secondary envelopment. Alphaherpesviruses (i.e., herpes simplex virus, varicella-zoster virus) usually gain their final envelope in vesicles derived from the trans-Golgi network and early endosomes - vesicles which are predominately positive for Rab5 (10). Betaherpesviruses (i.e., human cytomegalovirus), which are partially in the focus of this mini-review, reorganize already existing cellular compartments, where a lot of cellular markers (including those of trans-Golgi network, early endosomes, multivesicular bodies, and late endosomes) are present (11-13). The final envelopment of gammaherpesviruses (i.e., Epstein-Barr virus) occurs in the compartments showing characteristics of both cis- and trans-Golgi network (7).

\section{Cytomegalovirus life-cycle and maturation}

Cytomegalovirus (CMV) has linear DNA about 230 kbp long with 170 open reading frames (ORFs), which encode more than 250 gene products $(14,15)$. The execution of the gene program after infection includes a celltype-specific sequence of the gene expression during lytic infection, which results in cell disruption and infectious progeny release. The lytic infection seems to be restricted to a limited number of cell types in an immunocompetent host. Additionally, in some cell types, which are still unknown, the gene program is aberrantly executed, leading to the state of the life-long latency from which asymptomatic reactivation occurs throughout life and may lead to 
life-threatening conditions in immunocompromised individuals $(3,4,14)$.

The mechanisms of CMV infection and entry into the host cell are still unresolved. Altogether, it seems that infective CMV particles can penetrate the cell in two different ways. Both ways require virion binding to the corresponding receptors at the cell surface. After binding and tight attachment to the plasma membrane, the entire virion may be internalized into the endosomal system, move with endosomal vesicles and reach the cytoplasm by the release from the vesicle. Another way of virus entry is a direct fusion of the virion envelope with the plasma membrane, release of capsid into the cytosol, its attachment to microtubules and transport towards the nucleus using microtubule-dependent motor proteins (16).

The lytic type of infection, which results in the viral progeny production and cell lysis, can be divided into several different stages, according to the viral gene expression, assembly of the virus replication machinery in the nucleus and cytoplasm, and the sequence of host-cell reorganizations (17). The gene expression is highly coordinated and divided into at least three distinct phases: immediate-early (IE), early (E) and late (L) classes of genes/ proteins (18). IE proteins are, in fact, transcription factors that enable the transcription from the succeeding genes in the CMV genome (19). Early genes are expressed immediately after IE gene in a sequence that takes place 16-48 hours and leads to the establishment of molecular machinery which extensively reorganizes the host-cell organelles and cytoskeleton, rearranges several host-cell processes resulting in the hindering the host's immune system recognition and assemble replication machinery in the nucleus and cytoplasm for the production of new virions $(20,21)$. The assembly of viral DNA replication machinery in the nucleus results in the arrest in host-cell DNA synthesis and enables viral DNA replication, which initiates the expression of a large number of late genes and the late phase of infection. These genes continue to reorganize host-cell organelles, represent building components that incorporate into newly formed virions, and build several intracellular clusters that are required for the virion manufacturing processes $(22,23)$. The manufacturing of new virions requires the sequence of events that starts in the nucleus and continues through the cytoplasmic manufacturing stations, which involves the entire cell. Therefore, the entire host-cell is reorganized for virus manufacturing, and the whole sequence is often called the "virus factory."

The full replication cycle for human CMV (HCMV) lasts between 72 and 96 hours $(17,24)$, while murine CMV (MCMV) replication cycle length is shorter, and it takes between 24 and 48 hours to be completed (25). These two types of cytomegaloviruses are the most studied, although CMVs specific for other species also exist but are less studied. Given that $\mathrm{CMVs}$ are species-specific, i.e., murine cytomegalovirus can not be replicated on human cells and vice-versa (14), MCMV is usually used as a model to study HCMV infection due to the high level of similarity between their life cycles, the biology of infection in their native hosts and pathophysiological outcomes of infection. Cells infected with both types of cytomegaloviruses show similar cytopathological phenotypic characteristics, including the enlarged nucleus and the same type of nuclear inclusions, cell rounding, and development of sizeable cytoplasmic inclusion representing reorganized membranous system of the cell known as assembly compartment $(19,20)$. Furthermore, the shorter replication cycle of MCMV in the existing systems seems is beneficial for the cell biology studies of CMV replication cycle, and the outcomes of these studies can be easily tested in the animal models that mirror pathophysiological conditions of CMV infection in humans. Additionally, the manufacturing process of virion production during CMV infection is highly complex and still poorly understood. The shorter replication cycle of MCMV, thus, may facilitate the acquisition of knowledge about these processes that involve more than 1,500 hostcell factors (26).

The virion manufacturing involves a series of events that occur sequentially in the nucleus and the cytoplasm. The nascent capsids are assembled in the "nuclear viral factory " $(27,28)$, and they bud through inner nuclear envelope lammela. The lammela's composition is changed at this point during infection due to the insertion of the viral glycoproteins into it (Figure 1). This process is known as primary envelopment. According to the predominant conjectures, newly formed infective particles (virions) are transferred from inner to the outer nucleic membrane, but only the "naked "capsids are exported into the cytoplasm (29). There, it enters into the cytoplasmatic virion assembly compartment (cVAC), where the capsid acquires its tegument and envelope $(17,29)$. This is considered to be a secondary envelopment process, which is different from other members of the herpesvirus subfamily. Betaherpesvirus, in contrast to other herpesviruses, acquire their final envelope in the "chimera-like" compartment that shows markers from different cellular compartments at the same time, i.e., trans-Golgi network (TGN), endosomal recycling compartment, early endosomes and, perhaps, late endosomes (Figure 2). Given that the physiological relations between these organelles, especially at the interface among them, are still far from being fully resolved, it is not surprising that the processes of the secondary envelopment of CMVs and the mechanisms of the host-cell alterations during CMV infection are still poorly understood (30). Recent studies of the host-cell transcriptome $(26,30,31)$ and proteome (32) during CMV infection suggest that a spatio-temporal dynamic of a large number of host-cell factors (more than 1,500 ) is affected, including an extensive reorganization of their localization pathways. 


\section{Cytomegalovirus alters host-cell functions in the early phase of infection}

Cytoplasmatic viral assembly compartment (cVAC), a membranous structure where the process of secondary envelopment takes place, is formed from different cellular compartments. Since every cellular protein that resides in the membranous system of the cell has specific features determining its intracellular localization and lifetime, perturbation of the endosomal route of cellular proteins (including those involved in immune recognition and response) may result in specific changes of their cellular routing (33). These routes are usually monitored by mapping the presence of specific protein markers - either cargo material (i.e., MHC-I) or small GTPases (usually from Rab or Arf families). Rab/Arf proteins act as switches between different stages of endosome maturation.

Under normal physiological conditions, MHC-I molecules are constitutively internalized, but the majority of them are recycled back to the cell surface $(34,35,36)$. Their sudden downregulation from the cell surface during the first couple of hours of infection was, at first, explained with a disabled synthesis of new MHC-I combined with intensified degradation of the pre-existing MHC-I molecules, due to basic viral response of evading the innate immune response. However, if only these two processes were involved, the loss of the MHC-I molecules from the cell surface would have been much slower (approximately it would take 10 hours) then the one observed (within the first couple of hours of infection) $(37,38,39,40)$. Therefore additional viral interference in the cellular endosomal system must be taking place (41). It has been shown that during the early phase of infection with MCMV, a retention compartment is created, showing characteristics of completely mature early endosomes $(41,42)$. This means that this compartment shows both EEA1 and Rab5 proteins on its membranes (markers of early endosomes), but not late endosomal markers (i.e., lysobisphosphatic acid, LBPA). In this newly formed retention compartment, not only molecules that are transported by recycling (MHCI, transferrin receptor - TfR) pathways but also by endolysosomal (epidermal growth factor receptor, EGFR) ones (41) can be found. The surface expression of TfR in MCMV infected cells is also severely downregulated, probably due to the disarranging of the recycling machinery. This causes TfR to accumulate in the perinuclear region, together with the rest of the cargo material that is endocytosed both by clathrin-dependent and clathrinindependent endocytosis (43). Consequently, it is possible to conclude that in CMV infected cells, recycling pathways are impaired, as well as the maturation process from early to late endosomes. Finally, these changes result in the formation of a perinuclear retention compartment (33, 41). Further proof of this claim is the reduced protein amount of Rab11 and Rab7 in full cell lysates (41), the two markers that are essential in forming recycling and late endosomes, respectively $(44,46)$. The exact role of viral proteins in the endosomal pathways is not yet fully understood. Still, it is shown that early viral protein $\mathrm{m} 06$ can be found in the endosomal retention compartment, together with MHC-I molecules (42). This retention compartment, formed in the early phase of infection, serves as a foundation for the complete cVAC formation well into the late phase of CMV infection. At that point, several late $\mathrm{CMV}$ proteins essential for the virion formation (tegument and envelope) will also be located there. So, it is important to note that, even though the main function for which cVAC is formed only takes place well into the late phase of infection, the changes in the endosomal system begin already in the early phase of infection, probably under the influence of early viral proteins.

It is essential to point out that viral interference into the cellular endosomal system leads to retardation of the trafficking throughout it, but not the complete blockage of these processes. This is proven by overlapping of the cargo molecules with the usual fate of recycling (TfR) and endosomal degradation (EGFR) in cells infected with MCMV in the only place where their respective pathways merge - in the sorting endosomes (47). The agglomeration of the host cell protein markers of the corresponding endosomes further endorses this claim.

Similar changes in the endosomal system also appear in cells infected with HCMV. In that setting, the high level of endosomal remodeling is directly connected with the formation of the cVAC. This newly-formed compartment is round in shape, and in each infected cell, there is only one, even in the syncytium-like cells, there is only one copy of this compartment. cVAC is usually situated perinuclear in the cell, causing the nucleus to adopt a kidney-like shape $(21,48)$. It is important to note that cVAC composition is changing as the infection progresses through the temporal phases. Fully developed cVAC is an extremely complex structure composed of a large number of host-cell components. Alteration of the host-cell functions is associated with an alteration of more than one thousand host-cell genes $(26,30,32)$. The current knowledge about cVAC composition is summarized in Figure 2 .

After the CMV infection, the housekeeping cellular processes remain unaltered, but the entire cellular trafficking system is remodeled. To change these cellular mechanisms, it is required to comprehensively restructure the cytoskeleton as well as modulate the vast number of processes and proteins that take part in it. It was shown that HCMV infection alters the expression of over 2,000 genes connected to different aspects of cellular organelles, about 800 being downregulated and nearly 600 being upregulated, and the rest having some relative changes. The changes also appear both in spatial and functional clusters, i.e., the downregulated genes are vital in the early phase of infection. On the other hand, within the Golgi markers, those connected to intracellular transport 


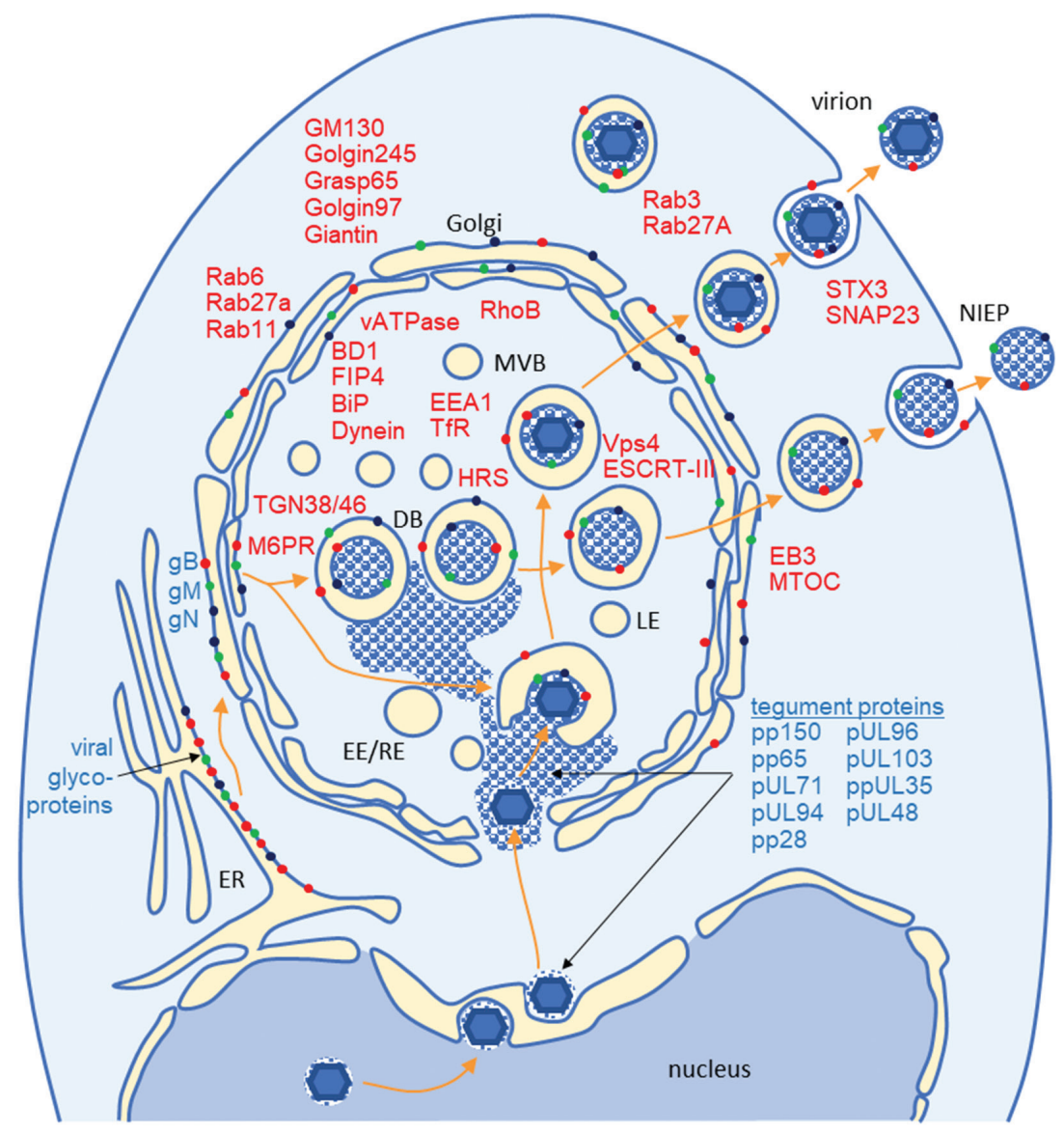

\section{References}

\begin{tabular}{|l|l|l|l|l|}
\multicolumn{1}{|c|}{ Recent reviews } & \multicolumn{1}{c|}{ HCMV } & \multicolumn{1}{c|}{ MCMV } \\
\hline Johnson and Baines, 2011 & Tooze et al., 1993 & Krzyzaniak et al., 2009 & Das and Pellet, 2011 & llić-Tomaš et al., 2010 \\
\hline Alvine, 2012 & Sanchez et al., 2000 & Tandon et al., 2009 & Hook et al., 2014 & Lučin et al., 2015 \\
\hline Henaf et al., 2012 & Homman-Loudiyi et al., 2003 & Cepeda et al., 2010 & Goulidaki et al, 2015 & Karleusa et al., 2018 \\
\hline Tandon \& Mocarski, 2012 & Das \& Pellet, 2007 & Womack and Shenk., 2010 & Rebmann et al., 2016 & Lučin et al., 2018 \\
\hline Owen et al., 2015 & Das et al., 2007 & Fraile-Ramos et al., 2010 & Pavelin et al., 2017 & \\
\hline Close etal., 2018 & Fraile-Ramos et al., 2007 & Indran et al., 2011 & Procter et al., 2018 & \\
\hline & Seo and Britt, 2007 & Schauflinger et al., 2011 & & \\
\hline & Tandon and Mocarski, 2008 & Cepeda \& Fraile-Ramos, 2011 & \\
\hline & & &
\end{tabular}

Figure 2. Summary of current knowledge about cytomegalovirus maturation. This model presents the prevailing view in the cytoplasmic virion assembly compartment ( $\mathrm{VVAC}$ ), viral proteins (glycoproteins and tegument proteins), and cellular organelle markers examined until now. Viral proteins are depicted in blue and cellular proteins in red. Viral tegument proteins are located in the center of the cylinder made of membranes that show markers of Golgi apparatus (i.e. Rab6, GM130, Golgin97 etc), recycling endosomes (i.e. Rab11) with inclusions derived from late and early endosomes. Therefore it is possible to strongly speculate that this is the place where final viral envelopment takes place. Abbreviations: DB, dense body; ER, endoplasmic reticulum; EE/RE, early endosomes/ recycling endosomes; LE, late endosomes; MVB, multivesicular body; NIEP, non-infectious enveloped particles. Presented data refer to the published research on HCMV (11, 12, 20, 21, 52, 55, 57, 63, 67, $68,72-75,77-80,81), \operatorname{MCMV}(32,40,42,43)$ and the most recent reviews about cytomegalovirus maturation $(10,29,30,56,61,76)$.

and membrane organization are upregulated, and those connected to the transport of organic substances are downregulated $(26,30,32)$.

\section{Cytomegalovirus assembly compartment}

The cytoplasmatic viral assembly compartment can not be created if there is no preceding viral DNA synthesis (50). This directly implies a correlation of cVAC formation with $\mathrm{L}$ gene expression, but at the same time, it does not exclude the possible connection of $\mathrm{E}$ genes and their products with the cVAC formation. In the cVAC, there are no traces of protein markers and/or cargo from the endoplasmic reticulum (Figure 2). Markers of ERGIC are situated radially, while the markers of the trans-Golgi network can be found on the outer parts of the cVAC (Figure 2). Marker of early endosomes (EEA1), usually dispersed throughout the cytoplasm (51), is clustered in the center of the newly-formed structure (52), together with checkpoint 
kinase 2 (Chk-2), a protein responsible for cell cycle control - regulating cell response to double-stranded DNA breakage (53). In the same area, Rab11, connected with recycling endosomes, is also accumulated $(20,52,54,55)$, as well as Arf6, a protein with a similar role in recycling processes (47). Late endosomal marker, Lamp1, was not found in the space occupied by cVAC, but it was found near the highly concentrated HCMV encoded glycoprotein $\mathrm{gH}$ (55). This newly-formed compartment also contains a CD63 molecule, specific for multivesicular bodies (MVB), implying its possible connection with the final assembly of viral particles and their release from the cell (21). The fact that CD63, EEA1, and TfR can all be found in the supernatant of the cells infected with MCMV supports this claim; however, it does not necessarily mean that they are also part of virions. Concurrent presence of these proteins can indicate active excretion of newlyformed virions from the infected cells (55).

The available data point that cVAC is formed by a massive restructuring of the secretory and endosomal organelles $(20,21,29,47)$. Membranes from endosomes and membrane compartments derived from the Golgi apparatus form the "viral factory" in the perinuclear area, while Golgi Apparatus, together with lysosomes, surrounds the actual location where the virions are assembled $(43,56)$. When observed from above, cVAC appears to be assembled from separate spheres, stacked upon each other, each one derived from distinct pre-existing endosomal vesicles. In short, cVAC is formed from existing membranes of the endosomal system, rearranged by the viral activity. 3D reconstruction of the cVAC shows that it is, in fact, a set of concentrically situated cylindrical structures, each derived from a distinct subset of endosomes (20).

One of the most noticeable changes in protein expression levels during CMV infection is the change of Rab27a levels. That is a protein that regulates secretion from the organelles related to lysosomes, but that are derived from late endosomes (13). This is a confirmation that HCMV uses the mechanism of endolysosomal secretion for its excretion. However, Rab27a-positive vesicles do not colocalize with the newly-formed cVAC and are found throughout the infected cells (47).

The early stages of the cVAC biogenesis are mostly unclear. Our studies on MCMV infected cells indicate that cVAC is initiated very early in the infection, at approx. $5-6$ hours post-infection $(43,47)$. The biogenesis appears to be associated with the reorganization and unlinking of the Golgi stacks, which also unlinks membranous system that participates in the trafficking between the transGolgi (TGN), early endosomal (EE) system and endosomal recycling system (ERC) (43). As a result of these unlinking events, several components of the membranous organelle system expand, such as elements at the interface between the TGN and the ERC, as well as EE and the ERC (43). Thus, it appears that host-cell factors regulating the Golgi ribbon and EE-ERC-TGN interface are targeted by $\mathrm{CMV}$ gene functions to initiate the $\mathrm{CVAC}$ formation. Studies in HCMV infected cells also demonstrated that targeting of Grasp65, a host-cell protein that maintains the integrity of the cis-Golgi, is associated with Golgi disassembly as the earliest event in HCMV cVAC biogenesis (57). Altogether, the studies on the biogenesis of cVAC are still in the initial phase, and a more in-depth analysis of a sequence of membranous system reorganization is required to reconstruct cVAC development and to construct the roadmap of host-cell alterations that are integrated into the cVAC biogenesis. Conclusions from the recent high-throughput studies on $\operatorname{HCMV}(26,30$, 32) suggest that these alterations involve perturbation of an extensive network of host-cell factors. They also include a quite complex roadmap of sequential events that initiate early in the infection and evolve through the phase of virion production and end in the latest phases of hostcell infection, including cell extinction.

The center of the structure of the proposed cVAC can be colocalized with the microtubule organization center (MTOC), and the importance of microtubules in the cVAC formation is proven by the use of nocodazole. To be precise, when applied, this reversible inhibitor of microtubule polymerization (58) also reversibly causes the breakdown of the cVAC and incapability of viral production $(12,59)$. Recent live-cell imaging studies (60) demonstrated impressive active movement, and changes in the position of the nucleus and Golgi derived structures in HCMV infected cells. These movements are associated with the inactivation of centrosomes and Golgi-derived nucleation of MTOCs outside the centrosomal area. These seminal studies suggest that the study of the cVAC biogenesis and physiology, including also other aspects of cytopathogenicity, should focus on live-cell imaging under conditions that minimally perturb host-cell functions.

\section{Egress of newly-formed CMV virions from the cell as a model for betaherpesviruses}

The egress of the newly-formed virions from the cell is a complex process. The necessary steps in this process are the same for all of the herpesviruses, and, as said before, the first step is the passing of the newly-formed nucleocapsid through the nuclear membrane, starting with primary virion envelopment in the inner nuclear membrane. Already at this time point, the viral glycoproteins envelop the virion, but while passing through the outer nuclear membrane, this primary layer of proteins is lost. The capsid delivered to the cytoplasm acquires the envelopment made of 16-35 tegument proteins. The general functions of these proteins are promoting the immediate-early phase of infection, arrest in host proteins expression together with transactivation of immediate early and early viral genes. The secondary envelopment occurs either at the TGN, Golgi, or some other endosomes in a still un- 
resolved way, resulting in the production of infective virions in the cellular vesicles. Afterward, they are transferred to the cell membrane, where they fuse with it, and virions are set free (61-63).

The mechanisms of virion egress of all of the herpesviruses are understudied and still poorly understood (30). Several studies tried to gain conclusions by the analysis of the composition of CMV virion particles (64-66). Lipidome analysis of the HCMV virion-particles revealed the composition similar to that of synaptic vesicles (63) and suggested the use of secretory vesicle-like pathway for virion egress. Although some regulatory components of the secretory vesicle pathway are recruited to the $\mathrm{VAC}$, such as Rab3 and Rab27A (67) and STX3 and SNAP23 elements of the SNAP/SNARE-complexes that mediate exocytosis of secretory vesicles $(66,68)$, their inhibition did not abolish egress suggesting the use of alternative pathways for betaherpesvirus egress. However, alternative routes have not been studied in that context. Recent studies indicate that CMVs may exploit the endosomal recycling system for cVAC development and organization as well as secondary envelopment and egress $(30,46,69)$.

\section{CONCLUSION AND PERSPECTIVES}

Even though at first glance, one could claim that the entire process of betaherpesvirus assembly and egress is well understood, only rough outlines regarding the final viral assembly and egress are somewhat known, as well as some of the changes in the remodeling of the endosomal system. It can be argued that the ambiguity and sometimes contrary findings and descriptions of this chimeralike compartment are a direct result of using mostly static methods, such as immunofluorescent microscopy, in order to follow a process that is the epitome of change and motion. Also, the disruption in functions of the endosomal system can be indirect proof of occurring change(s) and can indicate general pathways that are disrupted. Therefore, there is a high chance of overlooking quick changes that occur in the real-time, but are essential to viral assembly process and egress, or by having too short half-life to capture, or overlapping with several other pathways. Nowadays, new methods have been developed that could lead to a better understanding of the dynamic process of viral production, i.e., digital holotomographic microscopy (DHTM), that can, through livecell imaging, bring new insights to this complex process. If used wisely, this new method could show cellular changes taking place during CMV infection in real-time (combining low energy light microscopy with epifluorescence), and capture them as quickly as they occur. Therefore, it would be possible to notice even the most shortlived changes that could potentially be of great significance for the viral formation and egress but which are overseen with more conventional, static approaches.
Acknowledgments: This work was supported in part by the Croatian Science Foundation (grant IP-2014-9-9564 to $P L)$ and by the University of Rijeka (grants 13.06.1.1.4 to $P L, 13.06 .2 .1 .55$ to $H M L$, and 13.06.2.1.56 to GBZ).

\section{REFERENCES}

1. DAVISON AJ 2008 Herpesviruses: general features. In: Encyclopedia of Virology (Third ed.). Elsevier. pp. 430-436. https://doi.org/10.1016/B978-012374410-4.00683-X.

2. https://talk.ictvonline.org/taxonomy/

3. MANICKLAL $S$, EMERY VC, LAZZAROTTO T, BOPPANA SB, GUPTA RK 2013 The "silent" global burden of congenital cytomegalovirus. Clin Microbiol Rev 26: 86-102. https://doi:10.1128/CMR.00062-12.

4. BRITT WJ, PRICHARD MN 2018 New therapies for human cytomegalovirus infections. Antiviral Res 159: 153-74. https://doi:10.1016/j.antiviral.2018.09.003.

5. FOWLER KB, BOPPANA SB 2018 Congenital cytomegalovirus infection. Semin Perinatol 42(3): 149-154. https://doi.org/10.1053/j.semperi.2018.02.002

6. KRISHNA BA, WILLS MR, SINCLAIR JH 2019 Advances in the treatment of cytomegalovirus. Br Med Bull 131(1): 5-17. https://doi.org/10.1093/bmb/ldz031

7. NANBO A, NODA T, OHBA Y 2018 Epstein-Barr virus acquires its final envelope on intracellular compartments with golgi markers. Front Microbiol 9: 454. https://doi.org/10.3389/fmicb.2018.00454

8. SEVERI B, LANDINI MP, GOVONI E 1988 Human cytomegalovirus morphogenesis: an ultrastructural study of the late cytoplasmic phases. Arch Virol 98: 51-64. https://doi.org/10.1007/bf01321005

9. PIGNATELLI S, DAL MONTE P, LANDINI MP, SEVERI B, NASSIRI R, GILLOTEAUX J, PAPADIMITRIOU JM, SHELLAM GR, MERTENS T, BUSER C, MICHEL D, WALTHER P 2007 Cytomegalovirus primary envelopment at large nuclear membrane infoldings: what's new? J Virol 81: 7320-7321. https://doi.org/10.1128/JVI.00503-07

10. HENAFF D, RADTKE K, LIPPÉ R. 2012 Herpesviruses exploit several host compartments for envelopment. Traffic 13(11):14431449. https://doi.org/10.1111/j.1600-0854.2012.01399.x

11. TOOZE J, HOLLINSHEAD M, REIS B, RADSAK K, KERN H 1993 Progeny vaccinia and human cytomegalovirus particles utilize early endosomal cisternae for their envelopes. Eur J Cell Biol. 60(1): 163-178. PMID: 8385018.

12. SANCHEZ V, GREIS KD, SZTUL E, BRITT WJ 2000 Accumulation of virion tegument and envelope proteins in a stable cytoplasmic compartment during human cytomegalovirus replication: characterization of a potential site of virus assembly. J Virol. 74(2): 975-986. https://doi.org/10.1128/jvi.74.2.975-986.2000

13. FRAILE-RAMOS A, KLEDAL TN, PELCHEN-MATTHEWS A, BOWERS K, SCHWARTZ TW, MARSH M 2001 The human cytomegalovirus US28 protein is located in endocytic vesicles and undergoes constitutive endocytosis and recycling. Mol Biol Cell 12(6): 1737-49. https://doi.org/10.1091/mbc.12.6.1737

14. REDDEHASE MJ 2002 Antigens and immunoevasins: opponents in cytomegalovirus immune surveillance. Nat Rev Immunol 2(11): 831-44. https://doi.org/10.1038/nri932

15. RAWLINSON WD, FARRELL HE, BARRELL BG 1996 Analysis of the complete DNA sequence of murine cytomegalovirus. J Virol 70(12): 8833-8849. PMID: 8971012; PMCID: PMC190980.

16. MARSH M, HELENIUS A 2006 Virus entry: open sesame. Cell 124: 729-740. https://doi.org/10.1016/j.cell.2006.02.007 
17. BELTRAN JEAN PM, CRISTEA IM 2014 The life cycle and pathogenesis of human cytomegalovirus infection: lessons from proteomics. Expert Rev Proteomics 11(6): 697-711. https://doi.org/10.1586/14789450.2014.971116

18. CHAMBERS J, ANGULO A, AMARATUNGA D, GUO H, JIANG Y, WAN JS, BITTNER A, FRUEH K, JACKSON MR, PETERSON PA, ERLANDER MG, GHAZAL P 1999 DNA microarrays of the complex human cytomegalovirus genome: profiling kinetic class with drug sensitivity of viral gene expression. J Virol 73(7): 5757-5766. PMID: 10364327; PMCID: PMC112636.

19. TANG Q, MAUL GG 2003 Mouse Cytomegalovirus immediateearly protein 1 binds with host cell repressors to relieve suppresive effects on viral transcription and replication during lytic infection. J Virol 77: 1357-1367.

https://doi.org/10.1128/jvi.77.2.1357-1367.2003

20. DAS S, ORTIZ DA, GURCZYINSKI SJ, KHAN F, PELLETT PE 2014 Identification of human cytomegalovirus genes important for biogenesis of the cytoplasmic virion assembly complex. J Virol 88(16): 9086-9099. https://doi.org/10.1128/JVI.01141-14

21. DAS S, PELLETT PE 2011 Spatial relationships between markers for secretory and endosomal machinery in human cytomegalovirusinfected cells versus those in uninfected cells. J Virol 85(12): $5864-$ 5879. https://doi.org/10.1128/JVI.00155-11

22. CUEVAS-BENNETT C, SHENK T 2008 Dynamic histone H3 acetylation and methylation at human cytomegalovirus promoters during replication in fibroblasts. J Virol 82: 9525-9536. https://doi.org/10.1128/JVI.00946-08

23. GROOVES IJ, REEVES MB, SINCLAIR JH 2009 Lytic infection of permissive cells with human cytomegalovirus is regulated by an intrinsic "pre-immediate-early "repression of viral gene expression mediated by histone post-translational modification. J Gen Virol 90: 2364-2374. https://doi.org/10.1099/vir.0.012526-0

24. HALENIUS A, HAUKA S, DÖLKEN L, STINDT J, REINHARD H, WIEK C, HANENBERG H, KOSZINOWSKI UH, MOMBURG H, HENGEL H 2011 Human cytomegalovirus disrupts the major histocomaptibility complex class I peptide-loading complex and inhibits tapasin gene transcription. J Virol 85(7): 3473-3485. https://doi.org/10.1128/JVI.01923-10

25. REDDEHASE MJ 2013 Cytomegaloviruses - From Molecular Pathogens to Intervention, vol I. Poole, Caister Academic Press.

26. BELTRAN PMJ, MATHIAS RA, CRISTEA IM 2016 Portrait of the human organelle proteome in space and time during cytomegalovirus infection. Cell Syst. 3(4): 361-373.e6. https://doi.org/10.1016/j.cels.2016.08.012

27. GIBSON W 2008 Structure and formation of the cytomegalovirus virion. Curr Top Microbiol Immunol. 325: 187-204. https://doi.org/10.1007/978-3-540-77349-8_11

28. NGUYEN NL, LOVELAND AN, GIBSON W 2008 Nuclear localization sequences in cytomegalovirus capsid assembly proteins (UL80 proteins) are required for virus production: inactivating NLS1, NLS2, or both affects replication to strikingly different extents. J Virol. 82(11): 5381-5389.

https://doi.org/10.1128/JVI.02697-07

29. ALWINE JC 2012 The human cytomegalovirus assembly compartment: a masterpiece of viral manipulation of cellular processes that facilitates assembly and egress. PLoS Pathog 8(9): e1002878. https://doi.org/10.1371/journal.ppat.1002878

30. CLOSE WL, ANDERSON AN, PELLETT PE 2018 Betaherpesvirus virion assembly and egress. Adv Exp Med Biol 1045: 167-207. https://doi.org/10.1007/978-981-10-7230-7_9

31. KENNEDY MA, HOFSTADER WA, CRISTEA IM 2020 TRANSPIRE: A computational pipeline to elucidate intracellular protein movements from spatial proteomics data sets. J Am Soc Mass Spectrom 31(7): 1422-1439. https://doi.org/10.1021/jasms.0c00033
32. LUČIN P, MAHMUTEFENDIĆ H, BLAGOJEVIĆ ZAGORAC G, ILIĆ TOMAŠ M 2015 Cytomegalovirus immune evasion by pertrubation of endosomal trafficking. Cell Mol Immunol 12:154-169. https://doi.org/10.1038/cmi.2014.85

33. MAHMUTEFENDIĆ H, BLAGOJEVIĆG, KUČIĆN, LUČIN P 2007 Constitutive internalization of murine MHC class I moleculers. J Cell Physiol 210(2): 445-455. https://doi.org/10.1002/jcp.20877

34. MAHMUTEFENDIĆ H, BLAGOJEVIĆ G, ILIĆ TOMAŠ M, KUČIĆ N, LUČIN P 2011 Segregation of open major histocompatibility class I conformers at the plasma membrane and during endosomal trafficking reveals conformation-based sorting in the endosomal system. Int J Biochem Cell Biol 43(4): 504-515. https://doi.org/10.1016/j.biocel.2010.12.002

35. BLAGOJEVIĆ ZAGORAC G, MAHMUTEFENDIĆ H, ILIĆ TOMAŠ M, KUČIĆ N, LE BOUTELLIER P, LUČIN P 2012 Early endosomal rerouting of major histocompatibility class I conformers. J Cell Physiol 227(7): 2953-2964. https://doi.org/10.1002/jcp.23042

36. DEL VAL M, HENGEL H, HÄCKER H, HARTLAUB U, RUPPERT T, LUCIN P, KOSZINOWSKI UH 1992 Cytomegalovirus prevents antigen presentation by blocking the transport og peptideloaded major histocompatibility complex class I molecules into the medial-Golgi compartment. J Exp Med 176(3): 729-738. https://doi.org/10.1084/jem.176.3.729

37. REUSCH U, MURANYI W, LUCIN P, BURGERT HG, HENGEL H, KOSZINOWSKI UH 1999 A cytomegalovirus glycoprotein re-routes MHC class I complexes to lysosomes for degradation. The EMBO Journal 18(4): 1081-1091. https://doi.org/10.1093/emboj/18.4.1081

38. THÄLE R, SZEPAN U, HENGLE H, GEGINAT G, LUCIN P, KOSZINOWSKI UH 1995 Identification of the mouse cytomegalovirus genomic region affecting major histocompatibility complex class I molecule transport. J Virol 69(10): 6098-6105. PMID: 7666513; PMCID: PMC189506.

39. WAGNER M, GUTERMANN A, PODLECH J, REDDEHASE MJ, KOSZINOWSKI UH 2002 Major histocompatibility complex class I allele-specific cooperative and competitive interactions between immune evasion proteins of cytomegalovirus. J Exp Med 16: 805-816. https://doi.org/10.1084/jem.20020811

40. ILIĆ TOMAŠ M, KUČIĆ N, MAHMUTEFENDIĆ H, BLAGOJEVIĆ G, LUČIN P 2010 Murine cytomegalovirus perturbs endosomal trafficking of major histocompatibility complex class I molecules in the early phase of infection. $\mathrm{j}$ virol 84(21): 11101-11112. https://doi.org/10.1128/jvi.00988-10

41. KUČIĆ N, ILIĆ TOMAŠ M, MAHMUTEFENDIĆ H, BLAGOJEVIĆ G, LUČIN P. 2010 Early endosomal retention of murine cytomegalovirus m06 protein. Croat Chem Acta 85(2): 213-221. https://doi.org/10.5562/cca1816.

42. LUČIN P, KARELUŠA L, BLAGOJEVIĆ ZAGORAC G, MAHMUTEFENDIĆ LUČIN H, PAVIŠIĆ V, JUG VUČKO N, LUKANOVIĆ JURIĆ S, MARCELIĆ M, LISNIĆ B, JONJIĆ S 2018 Cytomegaloviruses Exploit recycling rab proteins in the sequential establishment of the assembly compartment. Front Cell Dev Biol 6: 165. https://doi.org/10.3389/fcell.2018.00165

43. GRANT BD, DONALDSON JG 2009 Pathways and mechanisms of endocytic recycling. Nat Rev Mol Cell Biol 10(9): 597-608. https://doi.org/10.1038/nrm2755

44. SAFTIG P, KLUMPERMAN J 2009 Lysosome biogenesis and lysosomal membrane proteins: trafficking meets function. Nat Rev Mol Cell Biol 10: 623-635. https://doi.org/10.1038/nrm2745

45. VANLANDINGHAM PA, CERESA BP 2009 Rab7 regulates late endocytic trafficking downstream of multivesicular body biogenesis and cargo sequestration. J Biol Chem 284(18): 12110-12124. https://doi.org/10.1074/jbc.M809277200 
46. KARLEUŠA L, MAHMUTEFENDIĆ H, ILIĆ TOMAŠ M, BLAGOJEVIĆ ZAGORAC G, LUČIN P 2018 Landmarks of endosomal remodeling in the early phase of cytomegalovirus infection. Virology 515: 108-122.

https://doi.org/10.1016/j.virol.2017.12.001

47. BUCHKOVICH NJ, MAGUIRE TG, ALWINE JC 2010 Role of endoplasmic reticulum chaperone BiP, SUN domain proteins, and dynein in altering nuclear morphology during human cytomegalovirus infection. J Virol 84: 7005-7717.

https://doi.org/10.1128/JVI.00719-10

48. WEEKES MP, TOMASEC P, HUTTLIN EL, FIELDING CA, NUSINOW D, STANTON RJ, WANG EC, AICHELER R, MURRELL I, WILKINSON GW, LEHNER PJ, GYGI SP 2014 Quantitative temporal viromics: an approach to investigate hostpathogen interaction. Cell 157(6): 1460-1472. https://doi.org/10.1016/j.cell.2014.04.028

49. HERTEL L, MOCARSKI ES 2004 Global analysis of host cell gene expression late during cytomegalovitus infection reveals extensive dysregulation of cell cycle expression and induction of pseudomitosis independent of US28 function. J Virol 78: 11988-12011. https://doi.org/10.1128/JVI.78.21.11988-12011.2004

50. PRICHARD MN, BRITT WJ, DAILY SL, HARTLINE CB, KERN ER 2005 Human cytomegalovirus UL97 kinase is required for the normal intranulear distribution of 9965 and virion morphogenesis. J Virol 79: 15494-15502.

51. SIMONSEN A, LIPPE R, CHRISTOFORIDIS S, GAULLIER JM, BRECH A, CALLAGHAN J, TOH BH, MURPHY C, ZERIAL M, STENMARK H. 1998 EEA1 links PI(3)K function to Rab5 regulation of endosome fusion. Nature 394:494-498. https://doi.org/10.1038/28879

52. DAS S, VASANJI A, PELLETT PE 2007 Three-dimensional structure of the human cytomegalovirus cytoplasmic virion assembly complex includes a reoriented secretory apparatus. J Virol 81: 1186111869. https://doi.org/10.1128/JVI.01077-07

53. GASPAR M, SHENK T 2006 Human cytomegalovirus inhibits a DNA damage response by mislocalizing checkpoint proteins. Proc Natal Acad Sci USA 103(8): 2821-2826. https://doi.org/10.1073/pnas.0511148103

54. AHLQVIST J, MOCARSKI E 2011 Cytomegalovirus UL103 controls virion and dense body egress. J Virol 85: 5125-5135. https://doi.org/10.1128/JVI.01682-10.

55. CEPEDA V, ESTEBAN M, FRAILE-RAMOS A 2010 Human cytomegalovirus final envelopment on membranes containing both trans-Golgi network and endosomal markers. Cell Microbiol 12(3): 386-404. https://doi.org/10.1111/j.1462-5822.2009.01405.x

56. TANDON R, MOCARSKI ES 2012 Viral and host control of cytomegalovirus maturation. Trends Microbiol 20(8): 392-401. https://doi.org/10.1016/j.tim.2012.04.008

57. REBMANN GM, GRABSKI R, SANCHEZ V, BRITT WJ 2016 Phosphorylation of Golgi peripheral membrane protein Grasp65 is an integral step in the formation of the human cytomegalovirus cytoplasmic assembly compartment. mBio 7: e01554-16. https://doi.org/10.1128/mBio.01554-16

58. KUHN M 1998 The microtubule depolymerizing drugs nocodazole and colchicine inhibit the uptake of Listeria monocytogenes by P388D1 macrophages. FEMS Microbiol Lett 160(1): 87-90. https://doi.org/10.1111/j.1574-6968.1998.tb12895.x

59. INDRAN SV, BALLESTAS ME, BRITT WJ 2010 Bicaudal D1dependent trafficking od human cytomegalovirus tegument protein pp150 in virus-infected cells. J Virol 84: 3162-3177. https://doi.org/10.1128/JVI.01776-09

60. PROCTER DJ, BANERJEE A, NUKUI M, KRUSE K, GAPONENKO V, MURPHY EA, KOMAROVA Y, WALSH D 2018 The HCMV Assembly compartment is a dynamic Golgi-derived
MTOC that controls nuclear rotation and virus spread. Dev Cell 45(1): 83-100.e7. https://doi.org/10.1016/j.devcel.2018.03.010

61. JOHNSON DC, BAINES JD 2011 Herpesviruses remodel host membranes for virus egress. Nat Rev Microbiol 22: 397-407. https://doi.org/10.1038/nrmicro2559

62. MEISSNER CS, SUFFNER S, SCHAUFLINGER M, VON EINEM J, BOGNER E. 2012 A leucine zipper motif of a tegument protein triggers final envelopment of human cytomegalovirus. J Virol. 86(6): 3370-3382. https://doi.org/10.1128/JVI.06556-11

63. SCHAUFLINGER M, FISCHER D, SCHREIBER A, CHEVILLOTTE M, WALTHER P, MERTENS T, VON EINEM J 2011 The tegument protein UL71 of human cytomegalovirus is involved in late envelopment and affects multivesicular bodies. J Virol 85: 3821-3832. https://doi.org/10.1128/JVI.01540-10

64. KATTENHORN LM, MILLS R, WAGNER M, LOMSADZE A, MAKEEV V, BORODOVSKY M, PLOEGH HL, KESSLER BM 2004 Identification of proteins associated with murine cytomegalovirus virions. J Virol 78: 11187-11197. https://doi.org/10.1128/JVI.78.20.11187-11197.2004

65. VARNUM SM, STREBLOW DN, MONROE ME, SMITH P, AUBERRY KJ, PASA-TOLIC L, WANG D, CAMP DG 2ND, RODLAND K, WILEY S, BRITT W, SHENK T, SMITH RD, NELSON JA 2004 Identification of proteins in human cytomegalovirus (HCMV) particles: the HCMV proteome. J Virol 78: 10960-10966.

https:/doi.org/10.1128/JVI.78.20.10960-10966.2004

66. LIU ST, SHARON-FRILING R, IVANOVA P, MILNE SB, MYERS DS, RABINOWITZ JD, BROWN HA, SHENK T 2011 Synaptic vesicle-like lipidome of human cytomegalovirus virions reveals a role for SNARE machinery in virion egress. Proc Natl Acad Sci USA 108: 12869-12874. https://doi.org/10.1073/pnas.1109796108

67. FRAILE-RAMOS A, CEPEDA V, ELSTAK E, VAN DER SLUIJS P 2010 Rab27a is required for human cytomegalovirus assembly. PLoS One 5: e15318. https://doi.org/10.1371/journal.pone.0015318

68. CEPEDA V, FRAILE-RAMOS A 2011 A role for the SNARE protein syntaxin 3 in human cytomegalovirus morphogenesis. Cell Microbiol. 13:846-58. https://doi.org/10.1111/j.1462-5822.2011.01583.x

69. ZELTZER S, ZELTZER CA, IGARASHI S, WILSON J, DONALDSON JG, GOODRUM F 2018 Virus control of trafficking from sorting endosomes. mBio 9: pii:e00683-18. https://doi.org/10.1128/mBio.00683-18

70. FRAILE-RAMOS A, PELCHEN-MATTHEWS A, RISCO C, REJAS MT, EMERY VC, HASSAN-WALKER AF, ESTEBAN M, MARSH M. 2007 The ESCRT machinery is not required for human cytomegalovirus envelopment. Cell Microbiol 9: 29552967. https://doi.org/10.1111/j.1462-5822.2007.01024.x

71. GOULIDAKI N, ALARIFI S, ALKAHTANI SH, AL-QAHTANI A, SPANDIDOS DA, STOURNARAS C, SOURVINOS G 2015 RhoB is a component of the human cytomegalovirus assembly complex and is required for efficient viral production. Cell Cycle 14: 2748-2763. https://doi.org/10.1080/15384101.2015.1066535

72. HOMMAN-LOUDIYI M, HULTENBY K, BRITT W, SODERBERG-NAUCLER C. 2003 Envelopment of human cytomegalovirus occurs by budding into Golgi-derived vacuole compartments positive for $\mathrm{gB}, \mathrm{Rab} 3$, trans-Golgi network 46, and mannosidase II. J Virol 77: 3191-3203. https://doi.org/10.1128/jvi.77.5.3191-3203.2003

73. HOOK LM, GREY F, GRABSKI R, TIRABASSI R, DOYLE T, HANCOCK M, LANDAIS I, JENG S, MCWEENEYS, BRITT W, NELSON JA 2014 Cytomegalovirus miRNAs target secretory 
pathway genes to facilitate formation of the virion assembly compartment and reduce cytokine secretion. Cell Host Microbe 15: 363-373. https://doi.org/10.1016/j.chom.2014.02.004

74. INDRAN SV, BRITT WJ 2011 A role for the small GTPase Rab6 in assembly of human cytomegalovirus. J Virol 85: 5213-5219. https://doi.org/10.1128/JVI.02605-10

75. KRZYZANIAK MA, MACH M, BRITT WJ 2009 HCMV-encoded glycoprotein M (UL100) interacts with Rab11 effector protein FIP4. Traffic 10: 1439-1457.

https://doi.org/10.1111/j.1600-0854.2009.00967.x

76. OWEN DJ, CRUMP CM, GRAHAM SC 2015 Tegument assembly and secondary envelopment of alphaherpesviruses. Viruses. 7(9): 5084-5114. https://doi.org/10.3390/v7092861

77. PAVELIN J, REYNOLDS N, CHIWESHE S, WU G, TIRIBASSI R, GREY F 2013 Systematic microRNA analysis identifies ATP6V0C as an essential host factor for human cytomegalovirus replication. PLoS Pathog 9: e1003820.

https://doi.org/10.1371/journal.ppat.1003820

78. SEO JY, BRITT WJ 2007 Cytoplasmic envelopment of human cytomegalovirus requires the postlocalization function of tegument protein pp28 within the assembly compartment. J Virol 81: 65366547. https://doi.org/10.1128/JVI.02852-06

79. TANDON R, AUCOIN DP, MOCARSKI ES 2009 Human cytomegalovirus exploits ESCRT machinery in the process of virion maturation. J Virol 83: 10797-10807.

https://doi.org/10.1128/JVI.01093-09

80. TANDON R, MOCARSKI ES 2008 Control of cytoplasmic maturation events by cytomegalovirus tegument protein pp150. J Virol 82: 9433-9444. https://doi.org/10.1128/JVI.00533-08

81. WOMACKA, SHENK T 2010 Human cytomegalovirus tegument protein pUL71 is required for efficient virion egress. MBio 1(5). https://doi.org/10.1128/mBio.00282-10 